\title{
Side-boat tow to Test the Influence of Flaps in a 2-meter Planing Craft Model
}

Remolque lateral de embarcación para comprobar la influencia de dispositivos sustentadores (flaps) sobre un modelo de embarcación de planeo de 2 metros

José R. Marín ${ }^{1}$

Daniela A. Benites ${ }^{2}$

\begin{abstract}
A small craft is considered in the planing regime when its Froude number is higher than 1.2, and under that condition its weight is mainly supported by hydrodynamic pressure acting on the bottom of the hull. It is also known that installing stern flaps at a certain angle from the bottom line will alter the trim angle and, as a consequence, the resistance exerted by the water. In this work, using the classical work from Savitsky, the resistance on a planing craft is estimated, including the effect of flaps, and then the influence of those appendages on the hydrodynamic behavior of a craft of local design was experimentally verified. The wooden model was 2.0 meters long and was side towed from an outboard powered boat, with a $3.2-\mathrm{m}$ arm, in a small artificial lake. The tests were run between 5 and 12 knots, with uneven intervals due to the outboard control; the model was towed without and with flaps at 5 and $10^{\circ}$. Finally, experimental and empirical results for towing force and trim angle were plotted. In some of the experimental curves the presence of humps may be identified, but less pronounced than with the theoretical results. Experimental resistance values are lower than those obtained from Savistky's formulation for no flaps; in the case of flaps at $5^{\circ}$, the agreement in trim angle was very good. Finally, the benefit of flaps on the performance of the planing model was corroborated, but it should be emphasized that this improvement is only valid for a certain velocity range.
\end{abstract}

Key words: Planing boat, model test.

\section{Resumen}

Se considera que un bote opera en el régimen de planeo cuando su número de Froude es mayor a 1.2, y en esa condición su peso es soportado principalmente por la presión hidrodinámica que actúa en el fondo del casco. También se sabe que el instalar flaps en la popa, a un cierto ángulo de la línea del fondo, alterará el ángulo de trimado y, como una consecuencia, la resistencia ejercida por el agua. En este trabajo, usando el método clásico de Savitsky, la resistencia sobre un bote planeador es estimada, incluyendo los efectos de flaps, y se verificó experimentalmente la influencia de esos apéndices sobre el comportamiento hidrodinámico de un bote de diseńo local. El modelo de madera tenía 2.0 metros de eslora, y fue halado por el costado de un bote impulsado por un motor fueraborda, con un brazo de $3.2 \mathrm{~m}$, en un pequeńo lago artificial. Las pruebas fueron desarrolladas entre 5 y 12 nudos con intervalos no uniformes debido al control del fueraborda; el modelo fue arrastrado sin y con flaps a 5 y $10^{\circ}$. Finalmente, los resultados empíricos y experimentales para la fuerza de halado y ángulo de asiento fueron graficados. En algunas curvas experimentales se puede identificar la presencia de máximos, pero menos pronunciados que con los valores teóricos. Los valores experimentales de resistencia son inferiores a los obtenidos con la formulación de Savitsky, para el caso sin flaps; en el caso con flaps a $5^{\circ}$, la concordancia en ángulo de trimado fue muy buena. Finalmente, el beneficio de flaps sobre el desempeño de un bote planeador fue comprobado, pero debe enfatizarse que esta mejora es sólo válida en un cierto rango de velocidad.

Palabras claves: Bote planeador, prueba de modelos.

Date Received: October 24th, 2010 - Fecha de recepción: 24 de Octubre de 2010

Date Accepted: January 17th, 2012 - Fecha de aceptación: 17 de Enero de 2012

\footnotetext{
${ }^{1}$ Faculty of Maritime Engineering, ESPOL. Guayaquil, Ecuador. e-mail: jrmarin@espol.edu.ec

${ }^{2}$ Naval Engineer, Guayaquil, Ecuador, e-mail: dbenites@espol.edu.ec
} 


\section{Introduction}

According to Brown (Brown and Savitsky, 1976), a boat enters the planing regime when its relative velocity, or velocity coefficient, is > 1.5; this parameter is equivalent to the Froude number, taking the beam at the chine as the representative length. Under this condition, the hydrodynamic pressure acting on the bottom lifts the hull, producing a significant change in draft, trim angle, and resistance (Faltinsen, 2005). It is also well known that installing a flap on the transom of the hull may help to reduce resistance; those devices having an angle with respect to the bottom develop a local hydrodynamic force, producing a change in trim and altering the longitudinal component of the normal force acting on the bottom of the boat.

Precisely installing flaps in the transom of planing boats has been an option that was locally considered, but due to lack of experience on their sizing, could not be implemented. That is the reason for this work.

Not many tests on planing boats with flaps installed on the stern of their hulls have been conducted, especially with the characteristics of local designs. Also, those tests are quite expensive and the size of the projects cannot justify their costs. Within this context, one option is to develop ship model tests towing them from a boat by using an adequate side arm. In this work, an experimental set to test a model of a planing boat was developed, including flaps at the transom (Benites, 2012). The model does not correspond exactly to the original boat, but to one with an increased deadrise angle.

\section{Description of the prototype boat}

The prototype boat is 11 meters long and it is intended for patrol duties in the port of Guayaquil, Ecuador; Table 1 presents main dimensions of the boat. It has prismatic shape from Midships, with a deadrise angle of $13^{\circ}$, and with a 32-knot design speed, powered by two 493-hp diesel engines impelling corresponding waterjets. Hull and superstructure were built with 5086 aluminum alloy.
Table 1. Main dimensions of prototype

\begin{tabular}{|c|c|c|}
\hline Overall length & 11.00 & $\mathrm{~m}$ \\
\hline Beam & 3.80 & $\mathrm{~m}$ \\
\hline Beam at chine & 2.40 & $\mathrm{~m}$ \\
\hline Depth & 1.70 & $\mathrm{~m}$ \\
\hline Deadriseangle & 13.0 & o \\
\hline
\end{tabular}

According to Brown (Brown and Savitsky, 1976), a boat is in the planing regime when the velocity coefficient reaches a value of about 1.5. This nondimensional parameter is defined as:

$$
C_{V}=\frac{v}{\sqrt{g b}}
$$

where $v$ is the boat velocity, $g$ is the gravitational acceleration, and $b$ is the beam at chine. In the present case, the boat's planning would start at a velocity of 18 knots. Given that the design speed is 32 knots, this craft is classified as a planing boat.

For the experimental development, an aluminum boat was available powered with a 40-hp outboard engine, reaching around 14 knots. Thus, equaling Froude numbers of the prototype, with $11 \mathrm{~m}$ and 32 knots, and the model, with the velocity of the boat to tow the model, a 2-meter length was obtained.

The final ship lines of the model are presented in Fig. 1. The main difference with the prototype considered is the deadrise angle, increased to $16.7^{\circ}$, and a change in the profile on the forward zone.

Once the model enters the planing regime, this part of the hull emerges completely out of the water; thereby, this geometric difference does not need to be further mentioned. Savitsky's calculations for comparison were developed with the model's deadrise angle.

At the transom of the model, flaps were installed on each side, completely covering the bottom. The chord of the appendages (dimension in the longitudinal direction) was $13 \mathrm{~cm}$. To change the 
Fig 1. Ship lines plan of the model
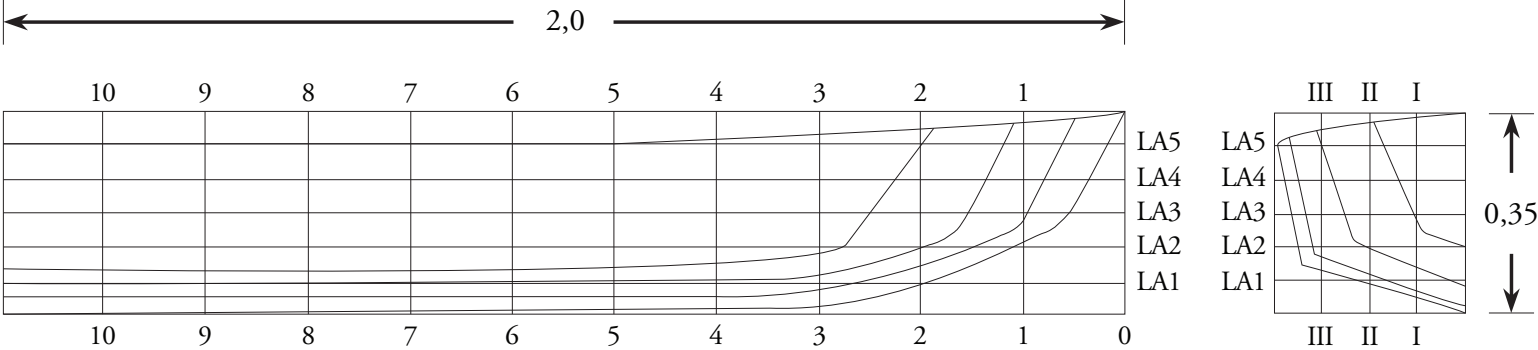

SHEER PLAN

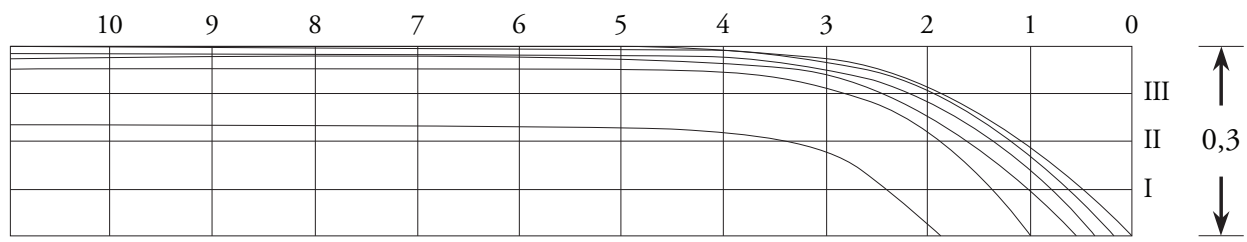

angle of the flaps, hinges and tensors were installed on each side, see Fig. 2.

Fig 2. Flaps at the transom of the model

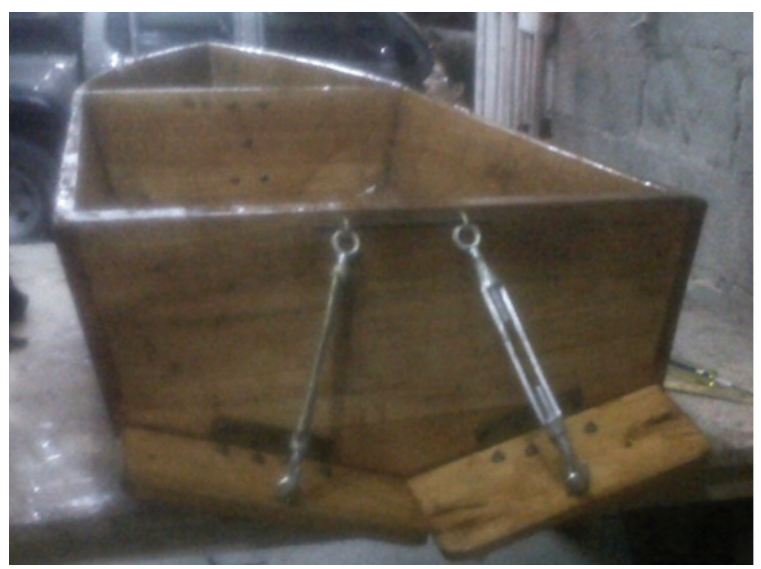

\section{Estimation of resistance by using Savitsky's method}

In spite of its age, Savitsky's method, (Savitsky, 1964), is probably the first option to estimate the resistance of a planing boat at a preliminary stage. In the present calculation, the influence of flaps was included, by following another Savitsky work, (Brown and Savitsky, 1976). Table 2 presents the two load conditions considered for the calculations, representing real ship situations.

Table 2. Load conditions for tests

\begin{tabular}{|c|c|c|c|}
\hline & Cond. 1 & Cond. 2 & \\
\hline Weight & 70.1 & 91.9 & $\mathrm{~kg}$ \\
\hline LCG, from trans. & 72 & 75 & $\mathrm{~cm}$ \\
\hline
\end{tabular}

To develop Savitsky's calculations, the following information was used for both conditions, see Table 3. Water density was measured and the kinematic viscosity was taken from table 10 in Principles of Naval Architecture (Van Manen, 1988), for fresh water at $25^{\circ} \mathrm{C}$ :

Table 3. Parameters for Savitsky's calculations

\begin{tabular}{|c|c|c|}
\hline Beam at chine & 58.4 & $\mathrm{~cm}$ \\
\hline VCG (scaledfromprot.) & 16 & $\mathrm{~cm}$ \\
\hline$\varepsilon$, thrust line angle & 4.31 & $\circ$ \\
\hline$f$, distance of thrust to $\mathrm{G}$ & 0.28 & $\mathrm{~m}$ \\
\hline$\rho$ (measured) & 1000 & $\mathrm{~kg} / \mathrm{m}^{3}$ \\
\hline$v$, kinematicvelocity & $0.939 \mathrm{E}-6$ & $\mathrm{~m}^{2} / \mathrm{s}$ \\
\hline
\end{tabular}


For all calculations, as recommended by Savitsky, the Frictional component of the resistance was estimated with the formula for $C_{f}$ from the American Towing Tank Conference (Van Manen, 1988). This is adequate for this close to $2 \mathrm{D}$ flow, produced when water flows on the flat bottom of the planing boat. In Table 4, trim angle and resistance force are reported for the model with no flaps in the two analyzed load conditions:

Table 4. Model resistance results with no flaps

\begin{tabular}{|c|c|c|c|c|c|}
\hline \multirow{2}{*}{$\mathbf{v}[\mathbf{k n}]$} & \multirow[b]{2}{*}{$\mathrm{C}_{\mathrm{v}}$} & \multicolumn{2}{|c|}{ Condition 1} & \multicolumn{2}{|c|}{ Condition 2} \\
\hline & & $\begin{array}{l}\text { Trim } \\
\text { [deg] }\end{array}$ & $\begin{array}{l}\text { Res. } \\
{[\mathrm{kg}]}\end{array}$ & $\begin{array}{l}\text { Trim } \\
\text { [deg] }\end{array}$ & $\begin{array}{l}\text { Res. } \\
{[\mathrm{kg}]}\end{array}$ \\
\hline 5.00 & 1.07 & 7.89 & 12.02 & 8.98 & 17.04 \\
\hline 6.00 & 1.29 & 8.97 & 14.91 & 10.33 & 22.08 \\
\hline 7.00 & 1.50 & 9.29 & 15.44 & 10.89 & 23.38 \\
\hline 8.00 & 1.72 & 8.91 & 14.68 & 10.59 & 22.29 \\
\hline 9.00 & 1.93 & 8.24 & 13.64 & 9.85 & 20.46 \\
\hline 10.00 & 2.15 & 7.49 & 12.73 & 8.99 & 18.73 \\
\hline 11.00 & 2.36 & 6.78 & 12.07 & 8.16 & 17.35 \\
\hline 12.00 & 2.58 & 6.14 & 11.65 & 7.39 & 16.34 \\
\hline 13.00 & 2.79 & 5.58 & 11.45 & 6.71 & 15.65 \\
\hline
\end{tabular}

To calculate resistance with flaps, two angles were considered, 5 and $10^{\circ}$, see results in Tables 5 and 6 :

Table 5. Model resistance results with flaps at $5^{\circ}$

\begin{tabular}{|c|c|c|c|c|c|}
\hline \multirow[b]{2}{*}{$\mathbf{v}[\mathbf{k n}]$} & \multirow[b]{2}{*}{$\mathrm{C}_{\mathrm{v}}$} & \multicolumn{2}{|c|}{ Condition 1} & \multicolumn{2}{|c|}{ Condition 2} \\
\hline & & $\begin{array}{l}\text { Trim } \\
\text { [deg] }\end{array}$ & $\begin{array}{l}\text { Res. } \\
{[\mathrm{kgg}]}\end{array}$ & $\begin{array}{l}\text { Trim } \\
\text { [deg] }\end{array}$ & $\begin{array}{l}\text { Res. } \\
{[\mathrm{kg}]}\end{array}$ \\
\hline 5.00 & 1.07 & 6.17 & 9.77 & 7.39 & 14.37 \\
\hline 6.00 & 1.29 & 6.34 & 10.95 & 7.81 & 16.90 \\
\hline 7.00 & 1.50 & 6.06 & 10.61 & 7.70 & 16.69 \\
\hline 8.00 & 1.72 & 5.39 & 9.73 & 7.10 & 15.22 \\
\hline 9.00 & 1.93 & 4.56 & 8.97 & 6.23 & 13.58 \\
\hline 10.00 & 2.15 & 3.71 & 8.58 & 5.30 & 12.30 \\
\hline
\end{tabular}

\begin{tabular}{|c|c|c|c|c|c|}
\hline 11.00 & 2.36 & 2.91 & 8.67 & 4.40 & 11.52 \\
\hline 12.00 & 2.58 & 2.18 & 9.33 & 3.57 & 11.28 \\
\hline 13.00 & 2.79 & 1.52 & 10.79 & 2.83 & 11.60 \\
\hline
\end{tabular}

Table 6. Model resistance results with flaps at $10^{\circ}$

\begin{tabular}{|c|c|c|c|c|c|}
\hline \multirow[b]{2}{*}{$\mathbf{v}[\mathbf{k n}]$} & \multirow[b]{2}{*}{$\mathrm{C}_{\mathrm{v}}$} & \multicolumn{2}{|c|}{ Condition 1} & \multicolumn{2}{|c|}{ Condition 2} \\
\hline & & $\begin{array}{l}\text { Trim } \\
{[\mathrm{deg}]}\end{array}$ & $\begin{array}{l}\text { Res. } \\
\text { [kg] }\end{array}$ & $\begin{array}{l}\text { Trim } \\
{[\mathrm{deg}]}\end{array}$ & $\begin{array}{l}\text { Res. } \\
{[\mathrm{kg}]}\end{array}$ \\
\hline 5.00 & 1.07 & 4.75 & 8.39 & 6.04 & 12.52 \\
\hline 6.00 & 1.29 & 4.26 & 8.74 & 5.75 & 13.54 \\
\hline 7.00 & 1.50 & 3.45 & 8.32 & 5.08 & 12.68 \\
\hline 8.00 & 1.72 & 2.46 & 8.16 & 4.13 & 11.48 \\
\hline 9.00 & 1.93 & 1.48 & 8.94 & 3.06 & 10.80 \\
\hline 10.00 & 2.15 & 0.66 & 11.58 & 2.02 & 11.16 \\
\hline 11.00 & 2.36 & 0.15 & 19.08 & 1.10 & 13.15 \\
\hline 12.00 & 2.58 & 0.00 & 62.09 & 0.41 & 18.47 \\
\hline 13.00 & 2.79 & - & - & 0.07 & 33.36 \\
\hline
\end{tabular}

Notice that with $10^{\circ}$ flap angle, in load condition 1 at 12.0 knots, the trim angle is null, and for 13.0, the iterative process could not reach a solution.

\section{Side tow test of the model}

To experimentally determine the behavior of the prototype, a $2.0-\mathrm{m}$ wooden model was built and it was towed by using an aluminum arm, $3.20 \mathrm{~m}$ long, installed on the side of the boat. The arm could be lifted with a cable through a pulley at the top of a vertical rod, so the tension on the model could be exerted in the direction of the propulsion force, as closely as possible, as recommended by the International Towing Tank Conference for High Speed Vessels (ITTC, 2002).

To register the results, a load cell and a 2-axis inclinometer were installed on the model, so milivoltages corresponding to pulling force and trim and heel angles could be stored in a portable 
computer via a data acquisition card. The scan rate employed was $120 \mathrm{scans} / \mathrm{sec}$. Also, a stream velocity meter was used for the boat/model speed, and a hand anemometer for wind velocity. The appendix shows a scheme of the equipment used for the tests.

The tests were carried out on July 2012 in a small artificial lake at the ESPOL Prosperina campus in Guayaquil. The water was considered fresh, at an average temperature of $25^{\circ} \mathrm{C}$, with a measured density of $1.00 \mathrm{gr} / \mathrm{cm} 3$. Because of the length of the lake, the model could not be towed more than 40 seconds on each test (at a 10-knot speed).

With Average and Standard deviation from the recordings, the Variation Coefficient was calculated (ratio of Standard Deviation/Mean*100), showing values below 10\% (see graph in the Appendix). Also, wind and model velocity show a similar behavior, allowing us to discard any negative influence from that parameter (see Figure in the Appendix).

\section{Experimental results: Condition 1 (70.1 kg)}

These tests included the model without flaps and with them at 5 and $10^{\circ}$. The initial conditions are presented in Table 7. Also, Fig. 3 presents photographs taken during some tests, including overall length and scaled values for mean wetted length.

Table 7. Initial conditions for test in load condition 1

\begin{tabular}{|c|c|c|c|}
\hline & No flaps & $\begin{array}{l}\text { Flaps } \\
\text { at } 5^{\circ}\end{array}$ & $\begin{array}{l}\text { Flaps } \\
\text { at } 10^{\circ}\end{array}$ \\
\hline Trim, $\left[{ }^{\circ}\right.$, +by stern $]$ : & 3.69 & 0.56 & 0.56 \\
\hline Heel $\left[^{\circ}\right]$ : & -0.52 & -0.42 & -0.52 \\
\hline
\end{tabular}

Experimental results: Condition $2(91.9 \mathrm{~kg})$

Table 8 presents the initial conditions and Fig. 4 shows photographs taken during the tests for the load condition 2 .

Fig. 3. Tests with no flaps in load condition 1
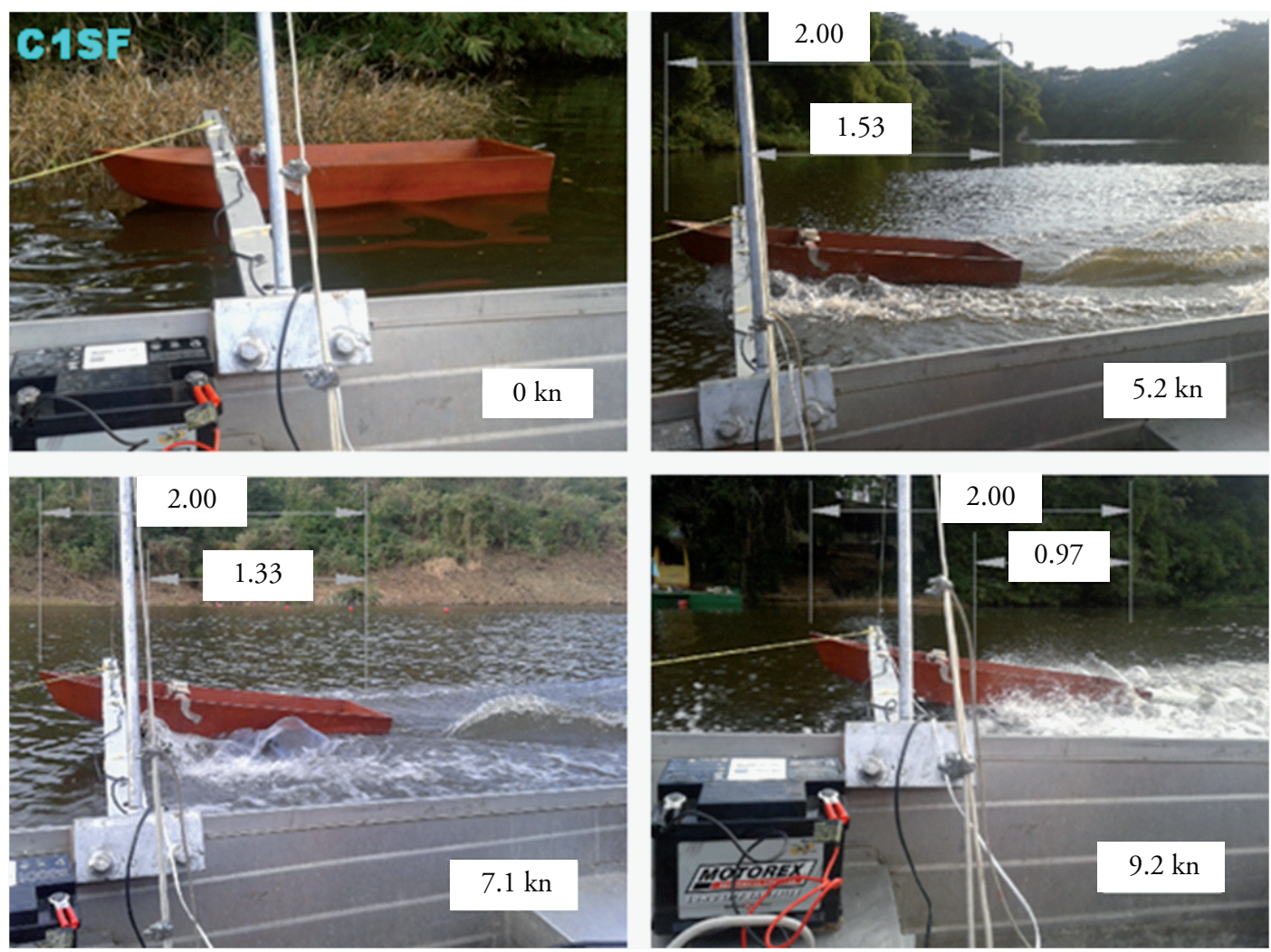
Table 8. Initial conditions for test in load condition 2

\begin{tabular}{|c|c|c|c|}
\hline & No flaps & $\begin{array}{l}\text { Flaps } \\
\text { at } 5^{\circ}\end{array}$ & $\begin{array}{l}\text { Flaps } \\
\text { at } 10^{\circ}\end{array}$ \\
\hline Trim, $\left[{ }^{\circ},+\right.$ by stern $]:$ & 4.74 & 0.13 & 0.03 \\
\hline Heel $\left[^{\circ}\right]$ : & 0.10 & -0.69 & -0.69 \\
\hline
\end{tabular}

\section{Analysis of Results}

In Figs. 5 and 6, towing force and heel angle with respect to the initial value are presented for the two load conditions for different speeds. The results by using Savitsky's method are also included. In the test with high flap angle, the bow wave from the towing boat collided with the wave from the model, producing some interaction and spray, wetting the interior of the model. Those results were considered unacceptable, and are not presented in the figures.
With no flaps, the coincidence in tendency for the trim angle can be noted, with a hump present at a slightly higher velocity; the experimental results present higher heel values. For flaps at $5^{\circ}$, the coincidence is very good in heel angles. For load condition 2 , the results are similar to those in the first condition.

Experimental resistance results with no flaps show lower values than the theoretical ones, also with the presence of a hump. It is noticeable that, theoretically and experimentally, flaps tend to reduce the mentioned force, up to a certain velocity. After that, resistance increases, that is, flaps are useful only in a certain velocity range.

As part of the Savitsky's results, the ratio of mean wetted length to beam at chine, called $\lambda$, is calculated. Also, by using photographs from the tests with no flaps, see Figs. 3 and 4, the

Fig. 4. Tests with no flaps in load condition 2
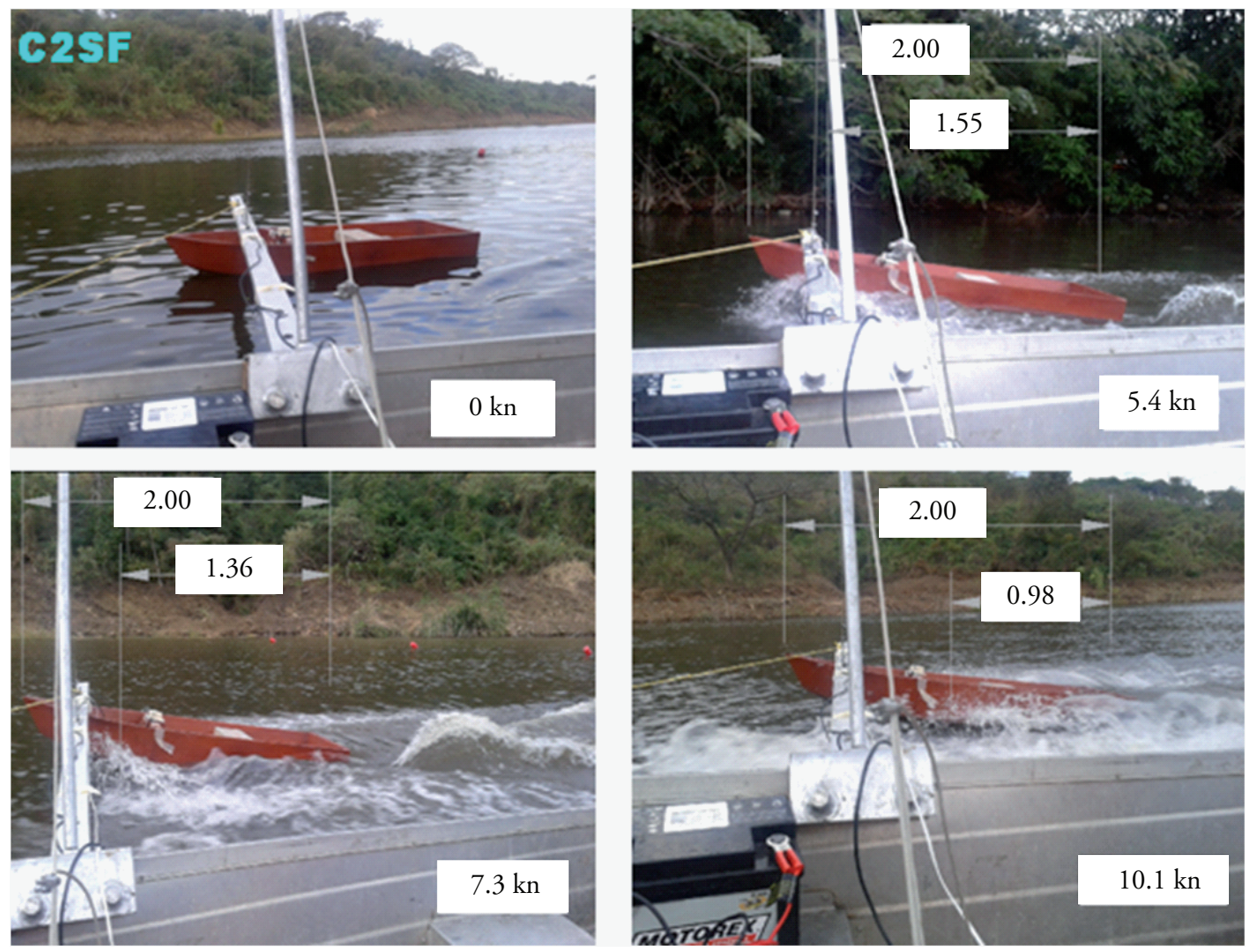
Fig. 5. Empirical and experimental results for load condition 1 (C1 SF SAV: Condition 1, No flaps, Savitsky's results; C1 SF E: Condition 1, No flaps, Experimental; C1 F5 SAV: Condition 1, Flaps at 5², Savitsky's results; C1 F5 E: Condition 1, Flaps at 5o, Experimental)
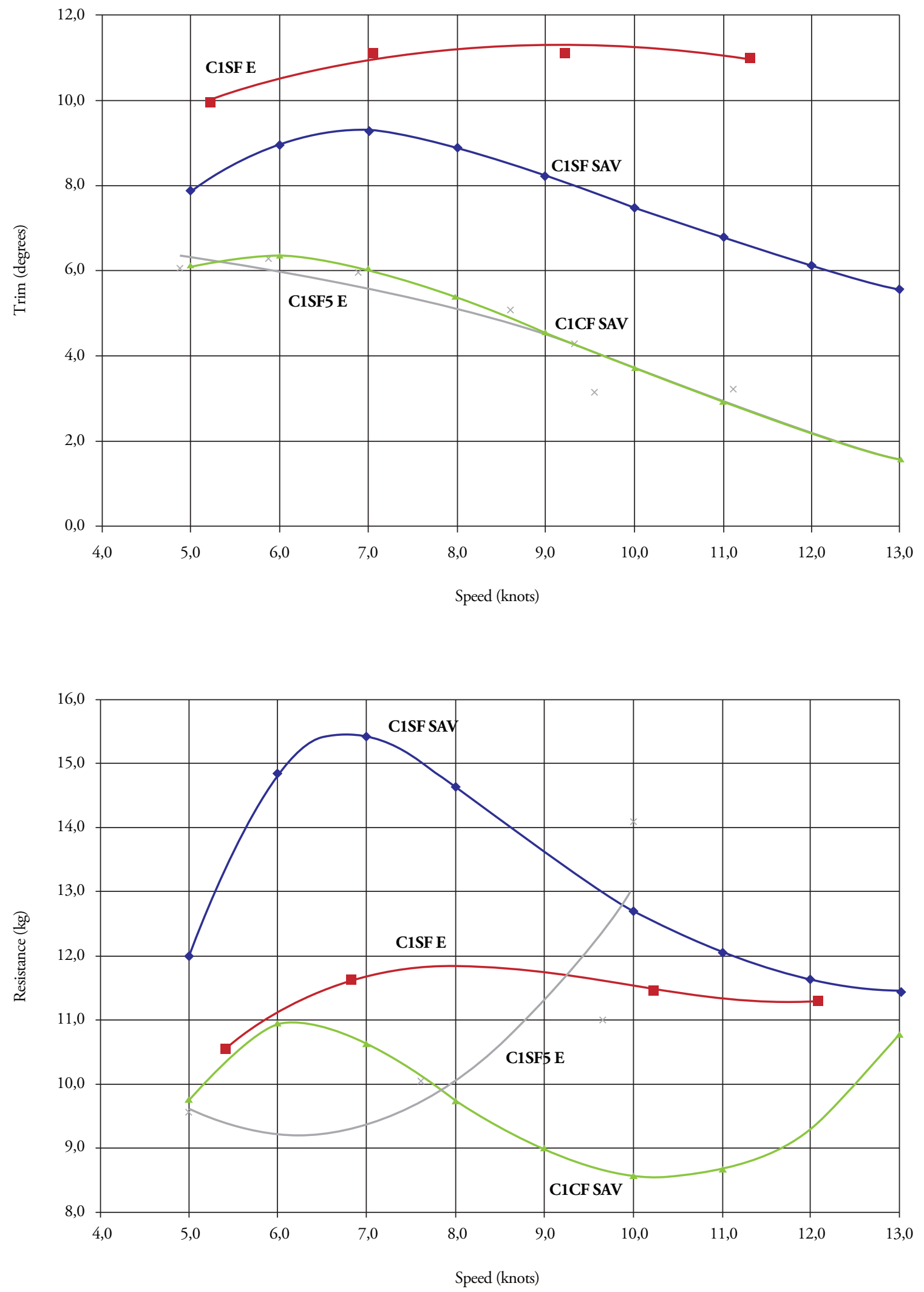
Fig. 6. Empirical and experimental results for load condition 1 (C2 SF SAV: Condition 1, No flaps, Savitsky's results; C2 SF E: Condition 1, No flaps, Experimental; C2 F5 SAV: Condition 1, Flaps at 5², Savitsky's results; C2 F5 E: Condition 1, Flaps at 5o, Experimental)
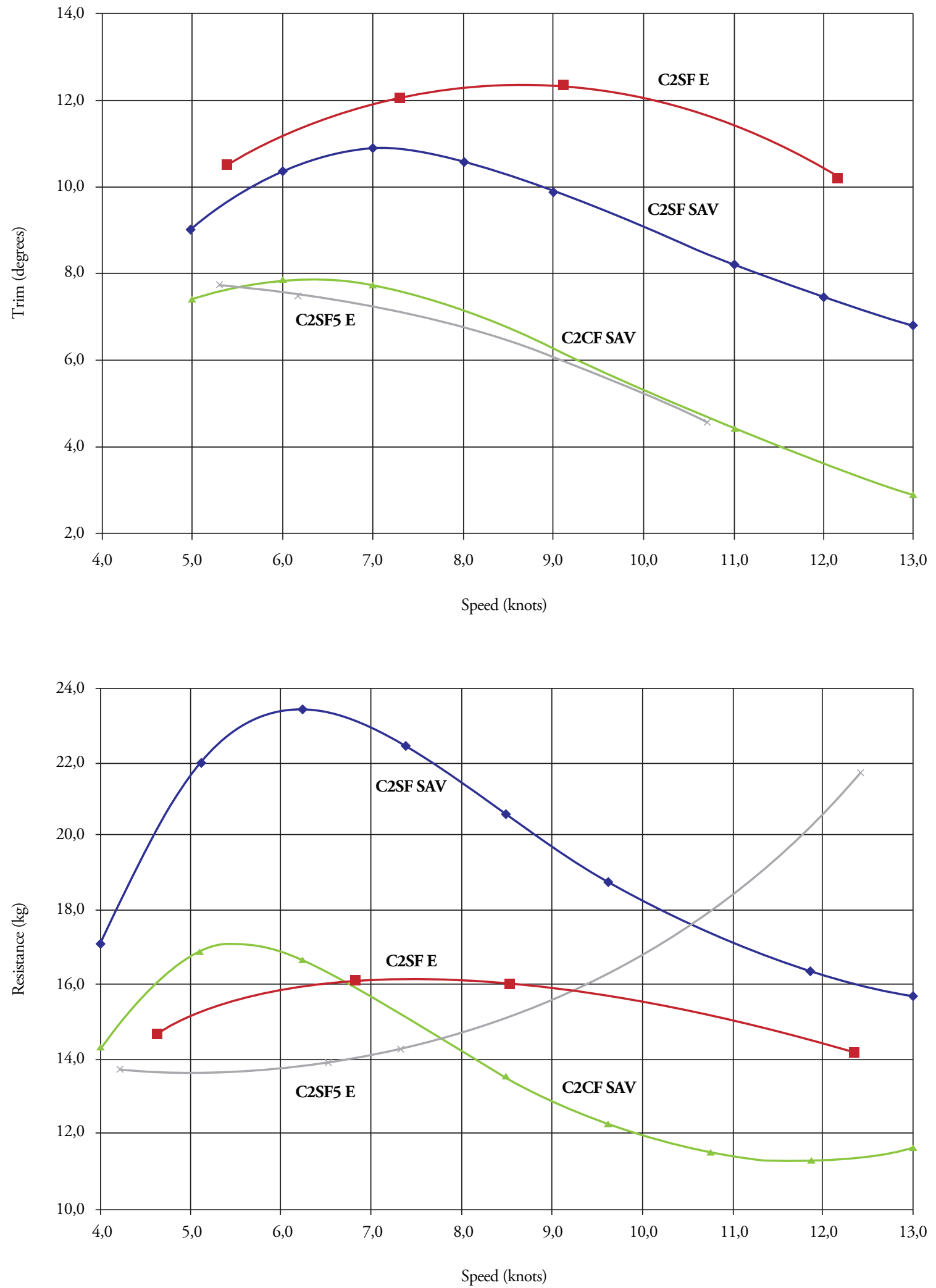
mean wetted length of the model was estimated. Following, in Fig. 7 theoretical and experimental values of the $\lambda$ ratio, are presented. Good agreement may be noted for the case of no flaps. In the tests with flaps, it is very difficult to estimate the wetted length from photographs (see appendix).

Fig. 7. Mean wetted length from tests with no flaps

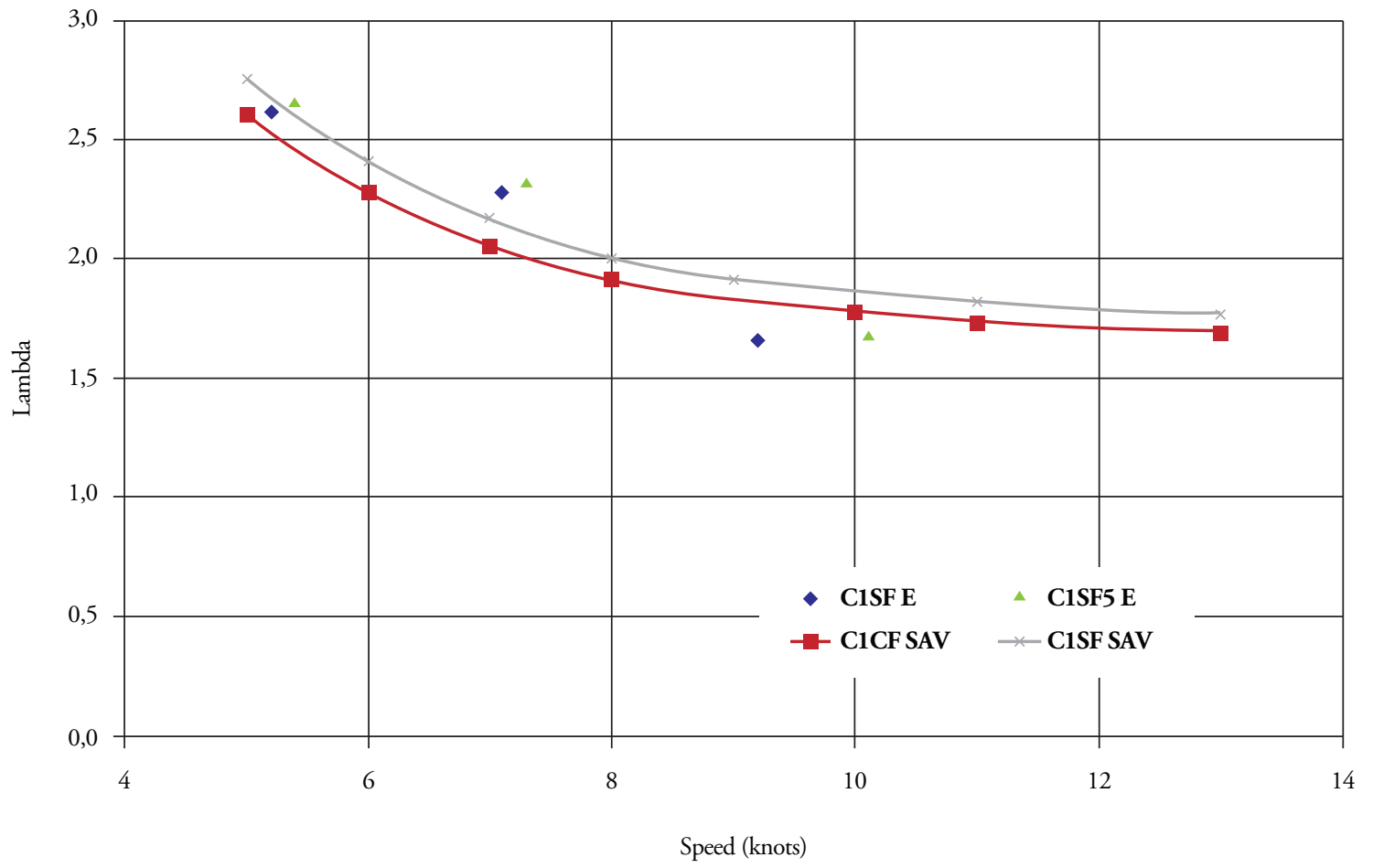

\section{Conclusions and Recommendations}

The experimental arrangement utilized for these tests is simple and inexpensive, but it presents several limitations, which we seek to minimize. These included controlling the presence of debris and obstacles in the trajectory of the towing boat and keeping boat velocity steady. The Variation coefficient shows values below $10 \%$, denoting that in spite of the limitations, recorded values may be considered useful.

Flaps are appendages that reduce the trim angle of a planing craft and also reduce the resistance exerted on the hull. But this benefit is limited to a certain velocity range. A boat designer must be aware that outside this range, flaps will increase resistance. Even though Savitsky's process to estimate improved boat performance is simple, experimental confirmation of results is always recommended.

\section{References}

BENITES, D. A., Pruebas Experimentales para Determinar la Influencia de Flaps en la Resistencia al Avance de una Lancha Planeadora de 11 metros, Naval Engineer Thesis, Faculty of Maritime Engineering, ESPOL, Guayaquil, Ecuador, 2012

BROWN, W. AND SAVITSKY, D., Procedures for Hydrodynamic Evaluation of Planing Hulls in Smooth and Rough Water, Marine Technology, SNAME, Vol 13, No.4, 1976.

FALTINSEN, O., Hydrodynamics of High-Speed Marine Vehicles, Cambridge University, 2005.

ITTC, Recommended Procedures and Guidelines - Testing and Extrapolation Methods (Resistance Test for High Speed Marine Vehicles), 7.5-02-05-01, 2002. 
SAVITSKY, D., Hydrodynamic Design of Planing Hulls, Marine Technology, SNAME, Vol. I, 1964.

\section{Appendix}

Arrangement of equipment on boat

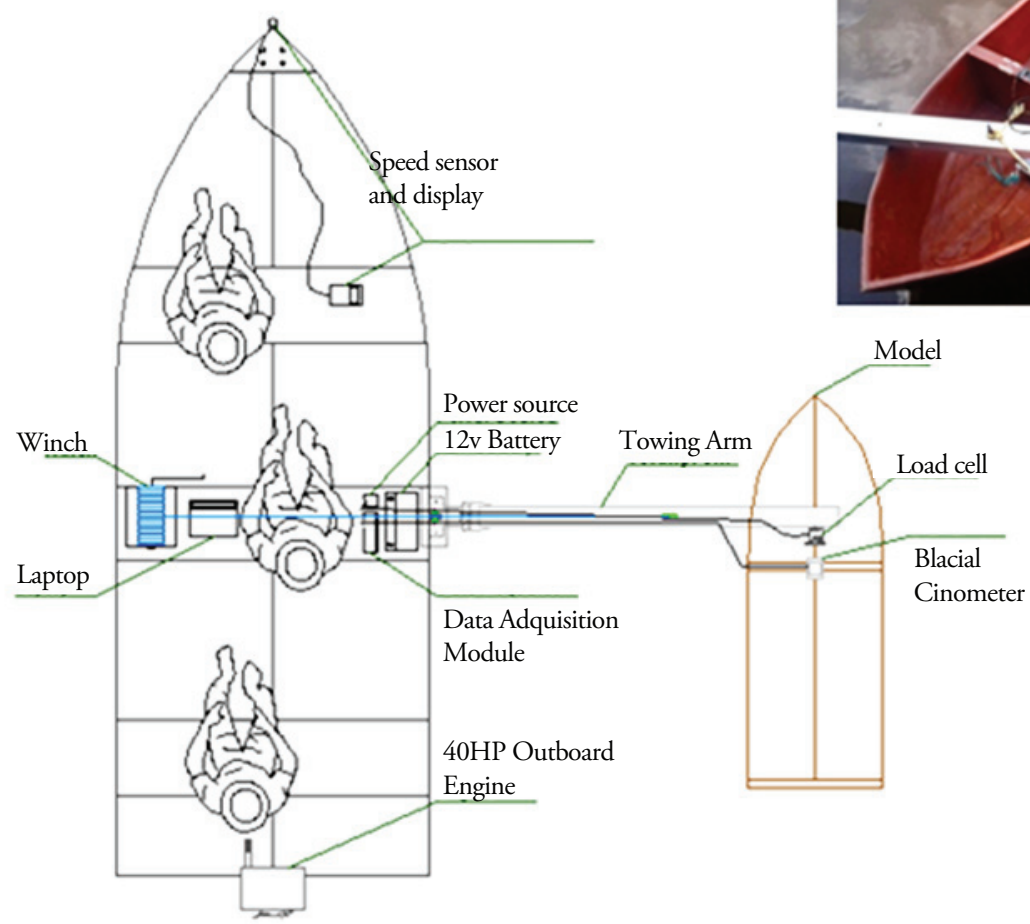

Variability of Test results

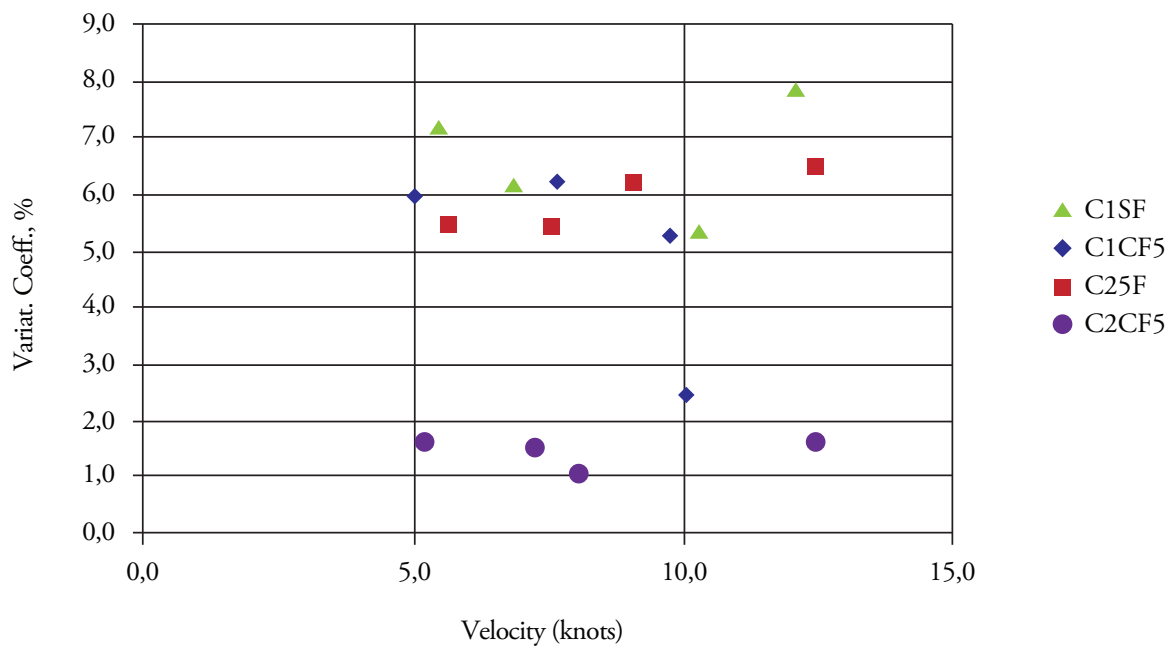

76 Ship Science \& Technology - Vol. 6 - n. ${ }^{\circ} 11$ - (67-68) July 2012 - Cartagena (Colombia) 
Wind velocity influence during tests

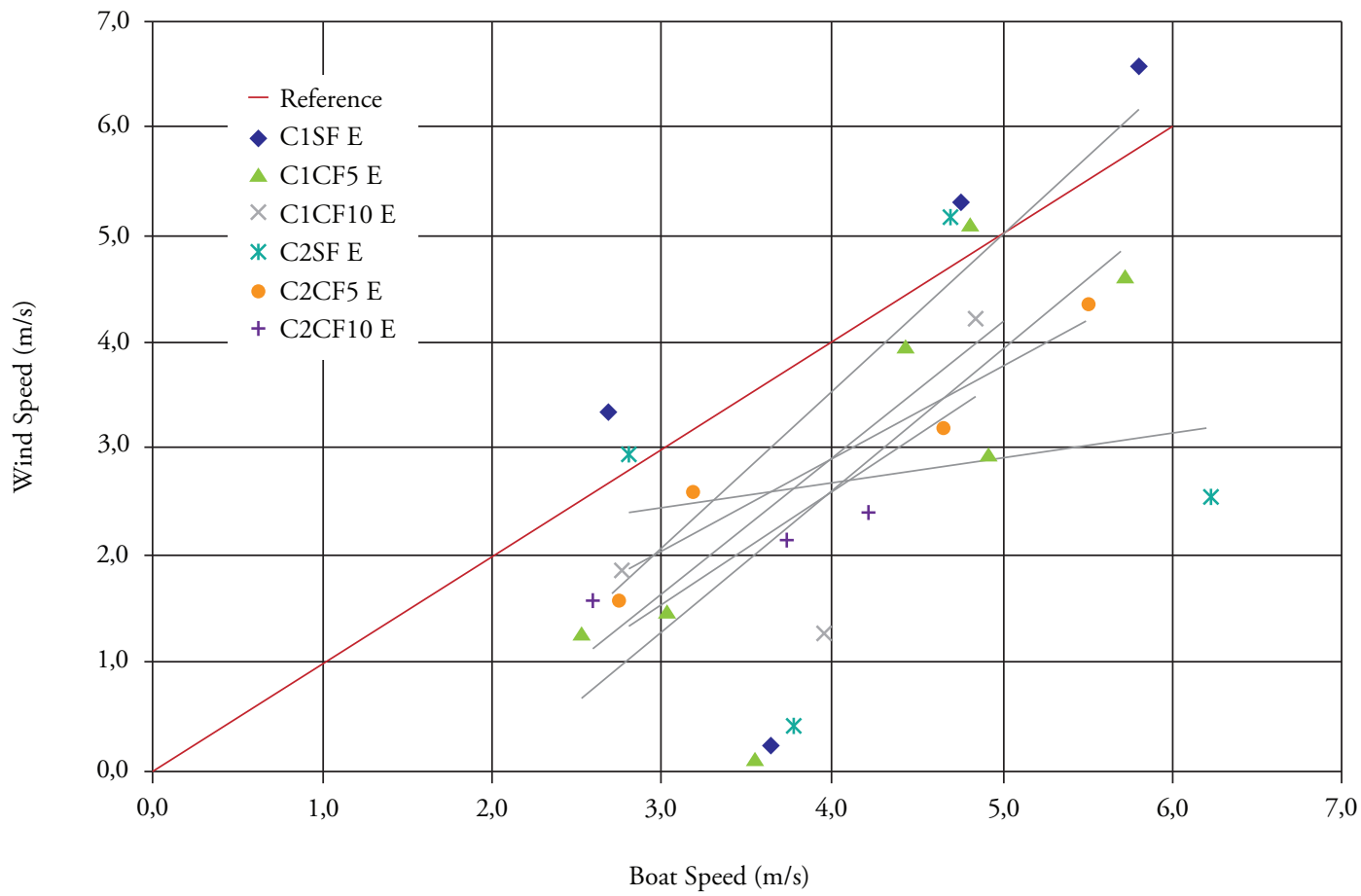

Tests with flaps at $5^{\circ}$ in load condition 1
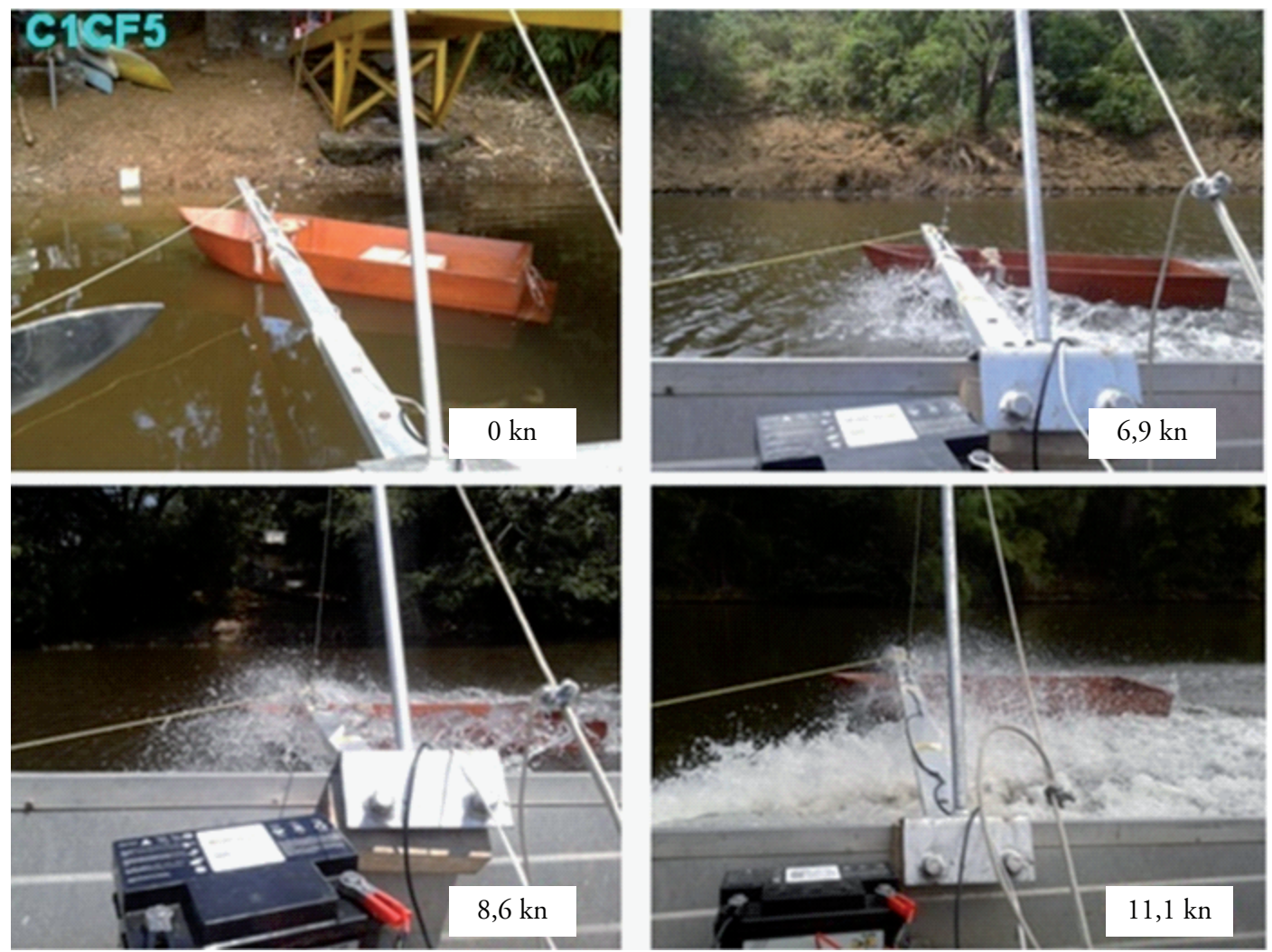
Tests with flaps at $5^{\circ}$ in load condition 2
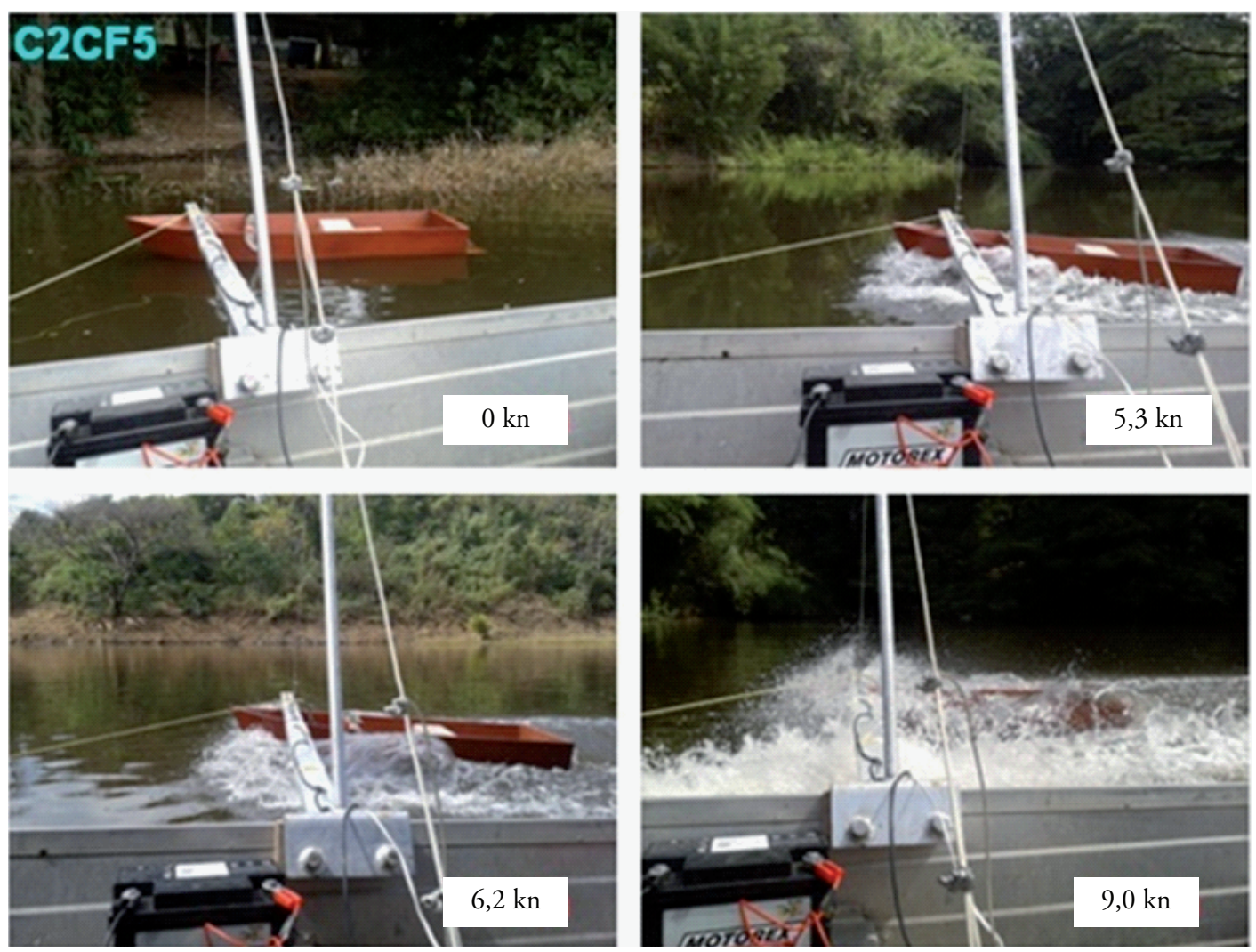